STATE OF ILLINOIS

DEPARTMENT OF REGISTRATION AND EDUCATION

DIVISION OF THE

NATURAL HISTORY SURVEY

STEPHEN A. FORBES, Chief

\begin{tabular}{lll}
\hline Vol. XIV. BULLETIN & Article I.
\end{tabular}

\title{
THE ORCHARD BIRDS OF AN ILLINOIS SUMMER
}

BY

STEPHEN A. FORBES

and

ALFRED O. GROSS,

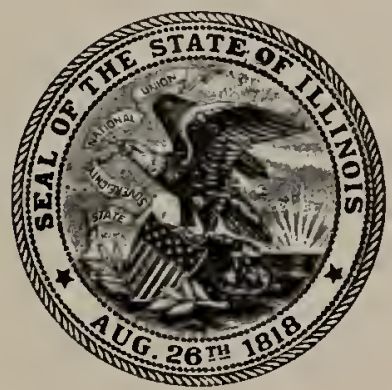

PRINTED BY AUTHORITY OF THE STATE OF ILLINOIS

URBANA. ILLINOIS

June, I92I 


\section{ERRATA}

Page 44, line 1 of text, for "sludge-worms" read midlge larvae, and for "larvae of the midges" read sludge-worms.

Page 188, line 4, for 3 read 23.

Page 216, last line, for "the opposite page" read proge ?1\%.

Page 267, delete line 13 from bottom.

Page 382, lines 3 and 5 from bottom, for "decrease" read change. 


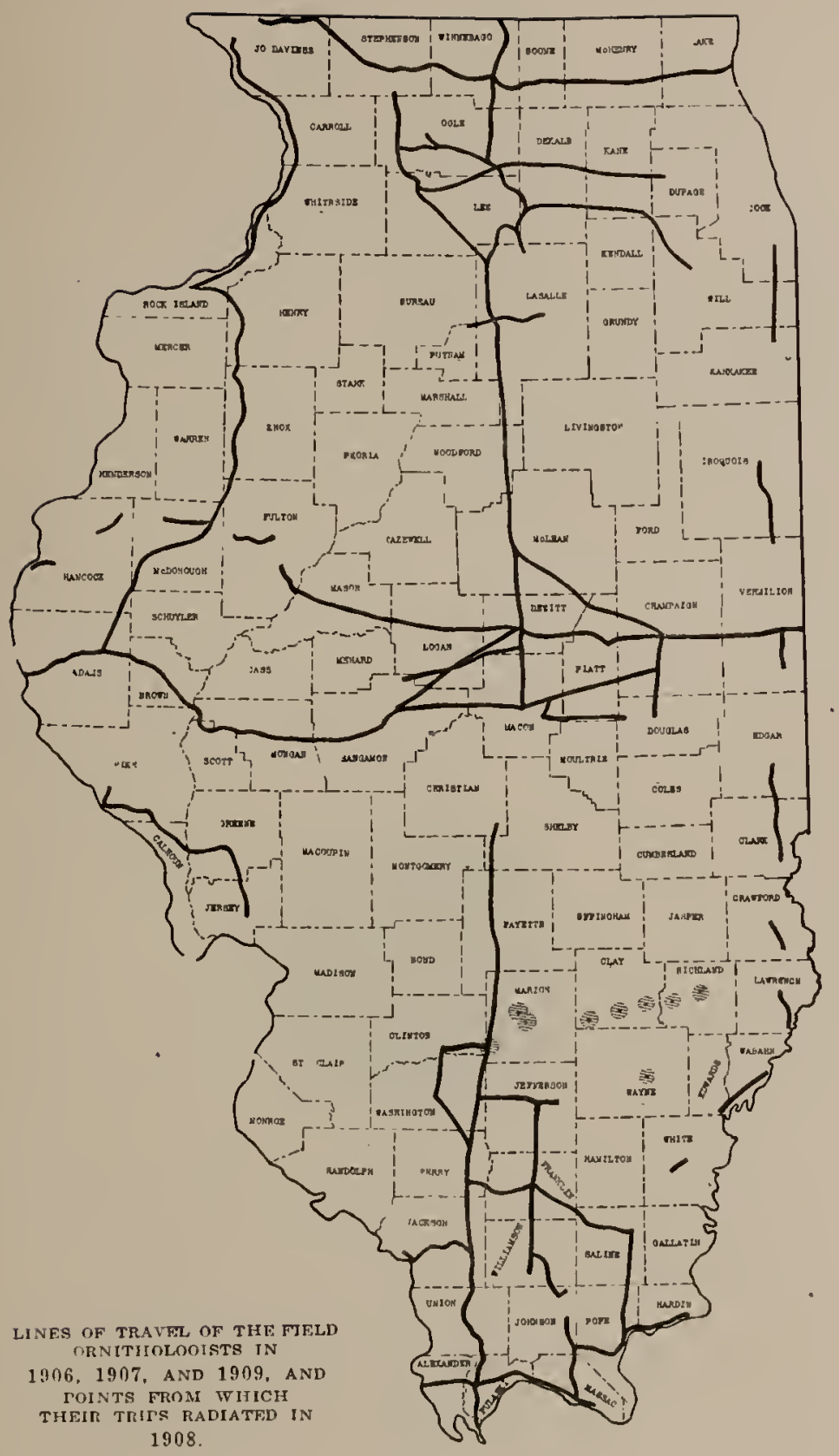


Article I.-The Orchard Birds of an Illinois Summer. BY Stephen A. Forbes and Alfred O. Gross.

From 1894 to $191 \%$ the Illinois State Laboratory of Natural History (since merged in the Natural History Survey of the State), of which the senior author of this paper was director, was active in quantitative studies of the plankton of the rivers and lakes of Illinois, making conmon use, in securing collections, of a ring net of very fine mesh, hauling it definite distances and at a fixed rate, measuring the product of each haul, identifying and sometimes counting the plankton organisms collected, bringing into comparison by this means the yield of different waters, situations, and seasons, and drawing such inferences as to cause and condition as were warranted by the data so obtained.

Having realized for many years the urgent need of numerical data concerning the species of birds in the state as indispensable to their valuation as ecological, and especially as economic, agencies it occurred to the senior author in 1905 that an equivalent of the plankton method might be used in the ornithological field by putting in place of the plankton net two men who should walk in parallel lines a definite distance apart, should identify and count all the birds flushed by them or crossing their track on a strip of a given width - say 150 feet-and should make at the same time a precise record of the kinds of surface and situations which they were traversing, of the distances traveled over each successively, and of the kinds of birds seen and the numbers of each kind on each such section of the 150-foot strip. The product of such a series of expert observations would be like that of a huge net a hundred and fifty feet wide, drawn in straight lines across every kind of crop or other surface vegetation,* by which all the birds found there should be caught and held until they had been identified and counted. The data so obtained would evidently be quite as useful for their purpose as those of the plankton net, and the results of their collation and analysis would be quite as dependable.

A satisfactory test of the method having been made during the summer of 1905 on a 400 -acre grain and stock farm belonging to the University of Illinois, two assistants were engaged, both students of the University at the time-one the junior author of this paper, who was responsible for the identification and counting of the birds, and the other a companion whose duty it was to walk at a measured pace at a fixed distance to the left of his leader, and to count and record the number of

* Forests of tall trees were avoided, since the birds there could not be listed exhaustively: and in orchards, the more open woods, patches of close shrubbery, and the like, the strip surveyed was usually narrowed to sixty feet. 


\title{
STATE OF ILLINOIS \\ DEPARTMENT OF REGISTRATION AND EDUCATION
}

W. H. H. MILLER, Director

\author{
BOÁRD OF \\ NATURAL RESOURCES AND CONSERVATION \\ W. H. H. MULER, Chairman
}

Willia a Treifase, Biology

John M. Coulter, Forestry

Rollin D. Salisburt, Geology

William A. NoYes, Chemistry
JoHN W. ALvord, Engineering

Kendric C. Baвeock, Representing the

President of the University of Intinois

THE NATURAL HISTORY SURVEY DIVISION

STEPIiEN A. Forbes, Chicf

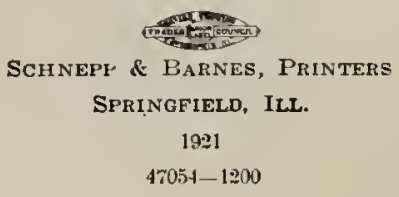


steps taken over each kind of situation. It was the original plan to devote a single year to these observations, dividing each of the successive seasons between the three sections of the state-northern, central, and southern-in such a way that we might have a detailed and carefully shaded picture of the bird life of each section in all four seasons of the year. This plan was carried through successfully for a year beginning August 29, 1906 ; and additional trips were made for special purposes during the late summer of 1908 and the entire summer season of 1909 . The distribution throughout the state of the trips of the bird observers during these years is shown in the accompanying map. These trips, all taken on foot, aggregated 2,825 miles, and on them 64,685 birds were recognized and counted.

Two brief papers have been published by the senior author on parts of the product of these trips, as prelininary examples of their use; one on "An Ornithological Cross-section of Illinois in Autumn,* and the other on "The Midsummer Bird Life of Illinois," the first based on a trip across the center of the state from the Indiana line to the Mississippi River, and the second treating of the summer data of the year $190 \%$

The widely separated residences of the present authors, one of us living in Maine and the other in Illinois, and the many engrossing preoccupations of both. have made it impossible until now for us to have the personal conferences or to provide for the cooperation necessary to a complete treatment of our subject; and it is with pleasure that we at last find ourselves in a position to work together through the mass of tables long ago made ready, and to avail ourselves, in their discussion, of the copious field notes and valuable reminiscenses of Professor Gross, often quite essential to an interpretation of our data. We now hope to prepare, without undue delay, a series of papers, the first of which is here presented.

\section{In SOUTHERN ILLINOIS}

Abundance of Birds in General.-In the summers of $190 \%$ and 1909 , statistical data of the bird life of southern Illinois were obtained by the methods above described, in the form of a record of the species of birds and the numbers of each found on $5,52 \%$ acres of land chosen entirely at random, and this showed that orchards were decidedly the favorite places of bird resort at that season and in that part of the state. While the general average number for the whole area studied was 768 birds to the square mile, the number to that area in the orchards traversed was 2,969 -or nearly four times the general ratio. Woodlands came next in density of the bird population, with 1,\%94 birds per square mile; yards and gardens third, with 1,339; and shrubbery fourth, with 1,054 to the mile. The high rank of yards and gardens as a bird resort was due mainly to the semi-domesticated English sparrow; and with this eliminated, orchards, open woodlands, and shrubbery-

* Bul. Ill. State Lab. Nat. Hist., Vol. VII, pp. 305-335.

† Ibid, Vol. IX, pp. 373-385. 
the "forest edge," in short-were found to be by all odds the favorite places of resort of the native southern Illinois species. The only other situation in which the numbers were above the average was pasture land, with $93 \pi$ to the square mile. The ratios in corn and oats were 423 and 419 to the nile, respectively. Other situations studied, and ratios in each, were stubble fields, 606 ; wheat and rye, 580 ; plowed ground, 626 ; waste and fallow, ?08; and swamps, 710 .

The more Abundant Species.-The most abundant bird in the area traversed was the English sparrow, about 14.5 per cent. of all the birds seen belonging to this species. Its average density in the whole area was 92 to the square mile, while in orchards it was 427 -that is, this species was between four and five times as abundant in orchards as its average for the general range. It was of course more abundant in yards and gardens, averaging there 597 to the square mile. In pastures and fields of small grain its numbers were 103 and 178 to the mile, respectively. These data are in evident agreement with what we know of the habits of the sparrows. As they both feed and nest most commonly in yards and gardens-that is, in the neighborhood of the house premises-they naturally resort to orchards most frequently for perching places-that is, for rest, shelter, and refuge. They are attracted to pastures by the fragments of grain to be found in the droppings of stock, and they turn to grain fields for food at harvest time. In meadows, on the other hand, they find little of either food or shelter, and hence average there only 53 to the square mile, or one sparrow to each twelve acres. English sparrows are not injurious in orchards, and their abundance there may be of some small benefit in their capture of insects, especially as food for their young.

Next on our list in order of abundance in orchards is the mourning dove. With a general average density of 60 to the square mile for the whole area, its ratio in orcluards was five times as great, or $29 \%$ to the mile. Its other ratios larger than its general average were stubble fields, 111 ; small grain, 102 ; plowed ground, 74 ; yards and gardens, 67. The number of this species in the orchard seems to have no economic significance, as the mourning dove feeds mainly on seeds of wild plants, and to some extent on grain. It nests largely in trees, and this is probably why the orchard is its favorite resting place.

The common quail, or "bob white," came next in order of numbers, according to our data derived from 241 quails seen on these trips, so distributed as to give us ratios of 289 to the square mile in orchards, 48 in shrubbery, 43 in stubble, 35 in woodlands, and 29 in grain fields, the other numbers being smaller than the general average for the whole area, which was 28 to the square mile. The number seen seems small for general conclusions; but the preference of the quail for orchards in southern Illinois is still more clearly shown by our more abundant data from commercial orchards, given on page $\%$ Evidently it is not the trees that attract it, but the cover afforded by an undisturbed growth of grass and weeds between the rows. Several nests 
of quail were found here, and this was the only situation in which the parent birds were seen with downy young.

If we may judge of the fitness of the common name of a bird from the outcome of our statistical tabulations, we should say that the next one on our list, commonly known as the field sparrow, ought to be named the orchard sparrow or the bush sparrow instead, (the last, indeed, a name given it by John Burroughs, ) for it was more abundant in orchards and in shrubbery than anywhere else, numbering 251 and $25 \%$ respectively to the square mile in these situations. Those in which it was next most abundant were open woods, with 88 to the square mile, and pastures and fields of waste and fallow land, with $5 \%$ to the mile in each. The average for the whole area covered was $3 \%$ to the square mile.

There can be no doubt of the correctness of the name of the orchard oriole, our data for which gave us an average of 168 to the square mile in orchards, with a general average for the whole area covered of only 12. Its only other habitat worth mentioning is yards and gardens, in which there werc 44 orioles to the square mile.

Our good little friend the robin, of which 164 were seen, was also largely an orchard and woodland bird, its density ratio being 145 to the mile in orchards and 89 in woodlands, with only 19 as an average for the whole area. Other notable ratios were 27 to the mile in past tures and 46 on plowed ground. Its frequency in farm orchards is probably due, like that of the English sparrow, to its general abundance atout the home prenises, from which an orchard is often the nearest available resort for shelter, rest, and nesting places.

The next species in order of abundance in orchards was the crow blackbird, or bronzed grackle. As represented by the $27 t$ of these birds seen, it was more abundant in orchards than in any other place. With a general average density of 32 to the mile, its numbers stood at $13 \%$ in orchards, 70 in open woods, 47 in farm yards, 46 in pastures, 32 in corn, and 31 in fields of wheat and rye, and it fell below its general average in all the other situations.

Next, the blue jay, although less frequently seen in orchards than any of the birds already mentioned, averaged there 114 to the square mile. It was still more abundant in open woods (195 to the mile), and much less so in pastures (24). Its general average for the whole area was only 13 to the square mile. It is thus essentially a woodland bird, resorting to orchards mainly because of their likeness to woods.

The mocking-birds seen on these southern Illinois trips numbered 115 , and the brown thrashers, $13 \%$, equivalent to 13 to the square mile for the mocking-bird and 16 for the brown thrasher-numbers perhaps too small from which to draw definite conclusions as to their preferred surroundings. So far as our data go, however, they indicate a decided preference of both these birds for orchards, the orchard ratio to the square mile being 84 for each. The mocking-bird was still more abundant in farm yards (113) and above its general average in gardens (38) and 
pastures ( 20$)$; and the thrasher was quite as frequent in open woods (88) as in the orchard, and above its average in waste lands and in pastures ( 23 in each).

There were 42 species of birds seen and recognized in orchards on these summer trips in southern Illinois, and these taken together averaged 2,9:1 to the square mile in that situation. On the other hand, the just-mentioned ten species taken together averaged 2,096 to the square mile in orchards; and we have only 875 to the square mile of orchards for all the other 31 species. That is, 82 per cent. of all the birds found in orchards belonged to 26 per cent. of the species, and all the others taken together average only a little more than one to the acre of orchard-much too few to have any great importance in that situation.

Farm and Commercial Orchards Comparcd.-The foregoing discussion of orchard birds is based on the data of a general survey of the country made without particular reference to any special kinds of crops, orchards being bronght into the account only as they chanced to lie in the lines of travel taken. The entire orchard area surveyed, in fact, aggregated only $8 t$ acres, which was about 1.5 per cent. of the whole area from which all the birds were determined. In order to get material for a better knowledge of the bird life of the southern Illinois orchard, a visit was made in 1908 to a commercial-orchard district extending from Centralia to Olney, and there the time was spent from August 19 to September 15 of that year, exploring orchards primarily, and other situations only as these were crossed in going from one orchard to another. The area covered by this survey aggregated 1,369 acres-about a fourth as much as was covered in the two summers of $190 \%$ and 1909 ; but the orchard tracts examined aggregated $\% 7 .+5$ acres instead of the $8+$ acres of the more general surveys, and taken together made more than 56 per cent. of the total area studied instead of the 1.5 per cent. in the other case.

The distances traveled on all these several journeys were $\% . S$ miles through farm orchards and 129 miles through commercial orchards, and in both cases all the birds on a strip sixty feet wide were determined and counted.

Several interesting differences were made out by a comparison of the products of these two kinds of surveys. In the first place. the number of birds per square mile of all crops was, as we shonld expect. considerably greater in the commercial-orchard district than in the farmland area-945 as compared with 769 - a difference of nearly a fourth in favor of the commercial-orchard district. Nevertheless, the number of birds per square mile of orchards was much greater in the general farm surveys of $190 \%$ and 1909 than in the orchard district survey of $1908-2.969$ to the orchard mile in the former and only 9.15 in the latter. That is, a square mile of commercial orchards contained only about a third as many birds on an average as a square mile of farm 
orchards. It is easy to see why this should be so. If, as we have already found to be the case, there are birds which resort to orchards for special purposes, we should expect to see them coming together in larger numbers to the unit of area in small, scattered orchards than in large orchards rather near each other. Indeed, we might well have expected that this concentration of birds in the orchards of a general farming district would have gone much farther than it has. In diminishing the ratio of orchards to other lands some thirty-seven times, we have increased the density of the bird population of the orchard only three times-evidence that the orchards are at best a convenience rather than a necessity to most of the birds which are found in them.

Comparing the lists of dominant species in the orchards of the two surveys, we find that while there were 42 species found in our 84 acres of farm orchards, 11 of which species made up 72 per cent. of the whole, there were 72 species found in the $\% \% 4.5$ acres of commercial orchards, 9 of which made up 87 per cent. of the whole number, and that 6 of the 9 dominant species were common to both lists. These were the quail, field sparrow, blue jay, mourning dove, brown thrasher, and English sparrow.

It was rather surprising to find the English sparrow first on the list of the most abundant farm-orchard birds and last on the corresponding commercial-orchard list, with $40 \%$ to the square mile in the first situation and only 56 in the second-seven or eight times as abundant in the farm orchard as in the commercial orchard; but this was no doubt due in great part to a fact already mentioned, that the center of abundance for this bird is in yards around the house and barn, and that it simply spreads from these to the adjacent orchards for shelter and refuge, with the result that its numbers per square mile of orchards is much smaller in a district where orchards are large and numerous than where they are small and few.

The fact that the number of mourning doves to the square mile was but $i \%$ in commercial orchards, while it was 297 in the small orchards of the farm, may have a similar explanation, the orchard being one of the favorite nesting places of this bird. On the other hand, the quail, the field sparrow, and the blue jay were even more abundant to the mile in the commercial than in the farm orchard, and the brown thrasher was but little less so: but the orchard oriole and the robin, occurring in farm orchards at ratios of 168 and 164 to the square mile respectively, were not once met with in the 129 miles of travel through these commercial orchards. This fact was due in all probability, to the relatively late period of the observations of 1908, falling, as they did. beyond the nesting season of these birds.

Orchard Birds par excellence.-In view of the fact that in the conmercial-orchard district only 56 per cent. of the area studied was actually in orchards, the remainder being made up of the ustual variety of farm situations, it seems to us that if there were distinctive orchard species of birds, they should be distinguished here by their much larger 
numbers per square mile in orchards than in miscellaneous situations; and an application of this test gives us the eight species of the following table, which may be taken, according to our data, as southern Illinois orchard-birds par excellence.

Principal Orchard Birds per Squake Mile, Southery Iluinots Survey,

SUMMER OF 1908.

Orchards compared with all other situations.

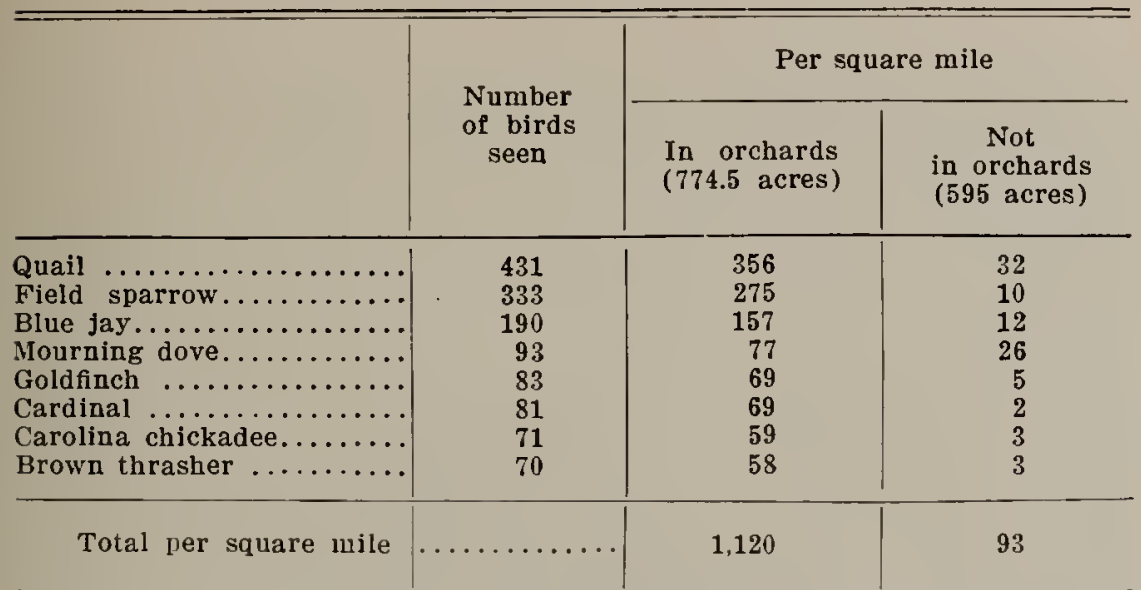

This small group of species seems strongly attracted to the orchard as the most desirable place of residence or resort, either for food, nesting, or shelter and refuge. of all the situations covered by our surveya peculiarity which distinguishes it from the other species of our list whose occurrence in orchards is occasional and temporary, or at most secondary to their choice of some other situation.

Economic Relations.-Taken as a whole, these orchard birds of southern Illinois, occasional visitors as well as resident species, are not directly injurious there to the orchard or its products, except as a few of them may eat cherries; and nearly all of them are more or less beneficial because of their partially insectivorous habits, especially when foraging for their young. Of course no such group of bird residents can be expected to keep the injurious insects of their neighborhood down to the level of harmlessness, but they may exercise a constant restraining infuence on insect multiplication and do their part towards cheching incipient uprisings of species whose rate of increase is temporarily stimulated by unusually favorable conditions.*

\section{In Central and Northern Illinois}

During the summers of $1906,190 \%$, and 1909, trips were made in northern and central Illinois similar to those above described for the

- See a paper by the senior author on "The Regulative Action of Birds upon Insect Oscillations," Bul. Ill. State Lab. Nat, Hist., Vol. I. Art. 6. 
southern part of the state, these northern and central trips covering 11,198 acres $(6,210.4$ acres in northern and $4,98 \% .87$ in central Illinois). Orchards were much less numerous, especially in northern Illinois, than in the southern part of the state, the area of farm orchards covered aggregating only 3.69 acres for the northern and 14.14 for the central part of the state, the former $.0 \%$ of 1 per cent. and the latter .3 of 1 per cent. of the whole area on which the birds were determined and counted. These areas seem to us too small for detailed discussion, but a comparison of the observations made in them with those of the 84 acres of southern Illinois gives us some interesting results.

Consistently with what has already been said, the orchard birds were more than twice as numerous per square mile in central and northern Illinois orchards as in the more numerous and extensive farm orchards of the southern part of the state, averaging 6,246 to the mile in place of 2,969 in southern Illinois. This preponderance was mainly due, however, to the abundance of the English sparrow, which made more than 68 per cent. of the number of birds seen in orchards. instead of the 14.5 per cent. in southern Illinois. This is consistent with conclusions drawn from the midsummer observations of $190 \%$, to the effect that the English sparrow diminished in numbers in that year from north to south.* Taking into account the native birds only, the ratios are $1,9 \% 4$ to the mile for the northern two-thirds of Illinois and 2,545 for the southern third; and this, again, agrees with the statement of the paper just cited, that the native sumner birds increased in number from north to south in $190 \%$. The larger number of the sparrow to the northward has also had the effect to reduce orchards to the second place on the list of situations preferred by birds, farm yards standing first.

\section{A BiRd's VIEW of THE ORChaRd}

An orchard is to us essentially a tract of land set to fruit trees in regular rows-in southern Inlinois almost entirely to apple, peach, or pear; but we have already seen evidence that to some of the birds inhabiting it the trees may be of secondary importance and perlaps of very little interest; and we shall fail to understand an orchard as a bird resort unless we view it with the eves of a bird instead of those of a man. It was, in fact, very obvious that a well-kept orchard, in which the ground was free from tall grass or bushes, was a rather poor place for birds (see Plates 1 and 2 ) but that one in which grass and weeds grew freely, and especially one in which dewberries and other shrubs were abundant, was a situation preferred above all others. It is this kind of ground-cover and the trees taken together-the latter useful to some for nesting and to nearly all for shelter against storms and for refuge from their enemies - which make up a complete bird orchard, answering to the essential needs of the orchard birds of this discussion (Plates $3-6)$.

* The Midsummer Bird Life of Illinois, Loc. cit., Vol. IX, pp. 373-3S5. 
Plate I

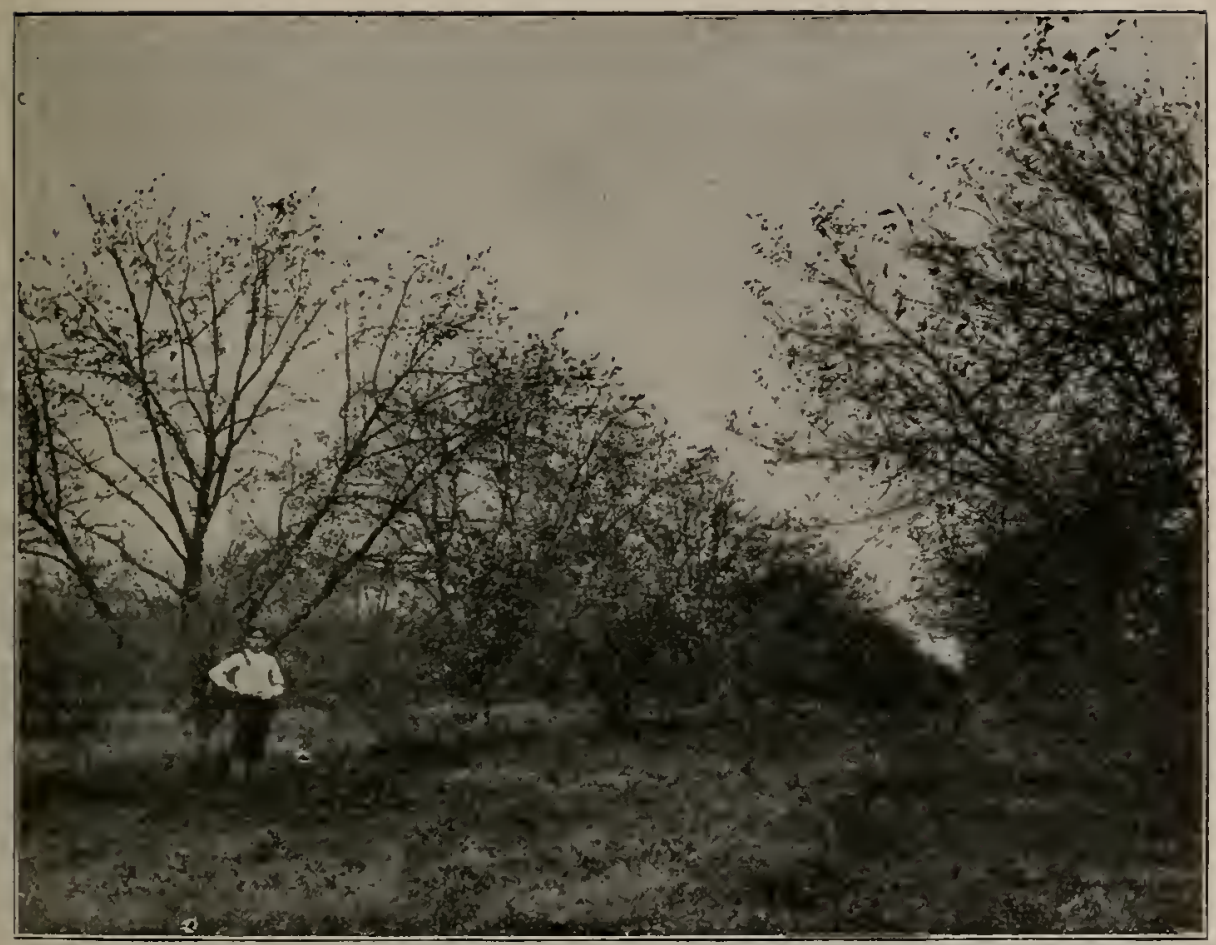

Clean orchard near Xenia, Clay Co. 
Plate II

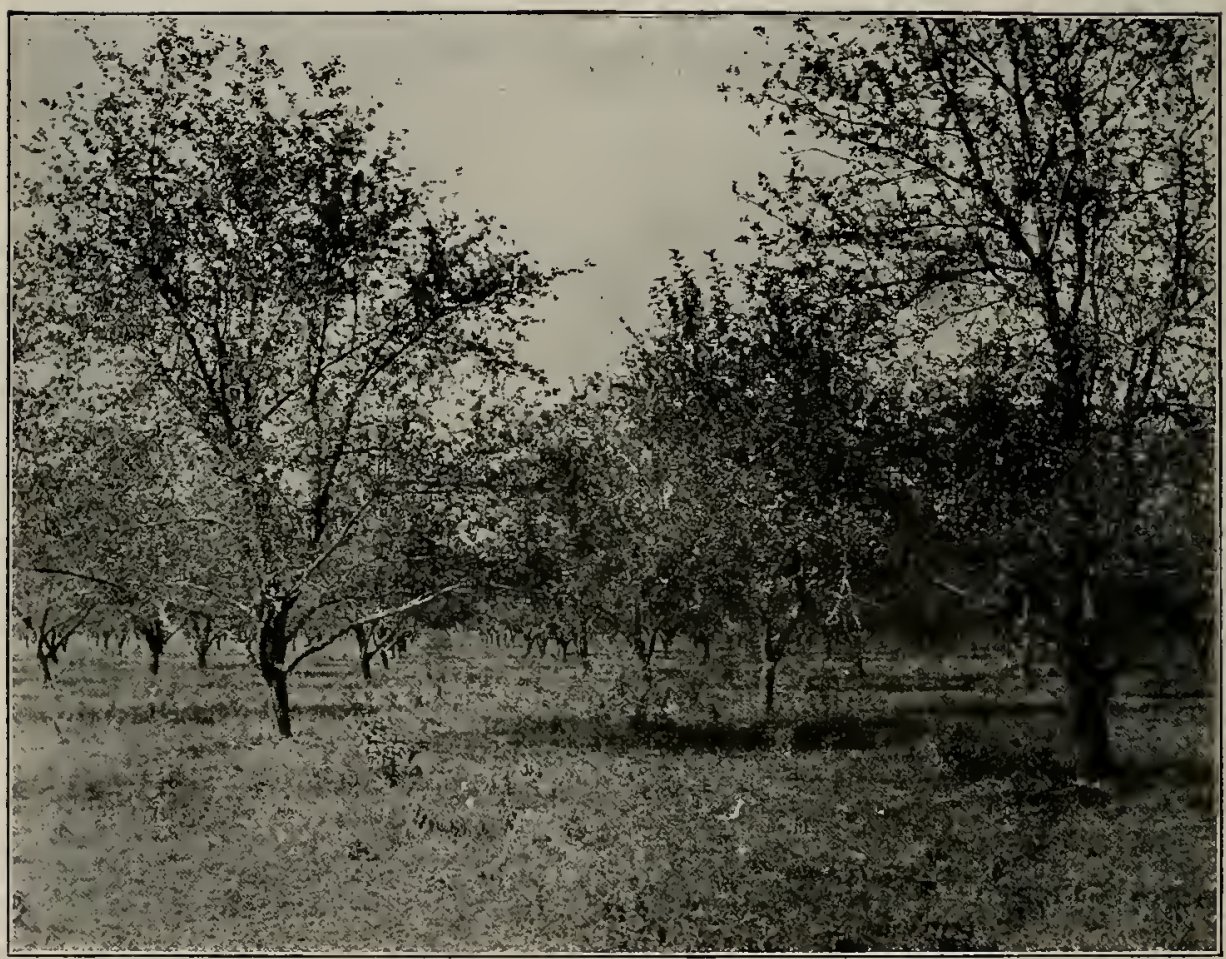

Clean orchard near Flora, Clay Co., Aug. 28, 1908. 
Plate III

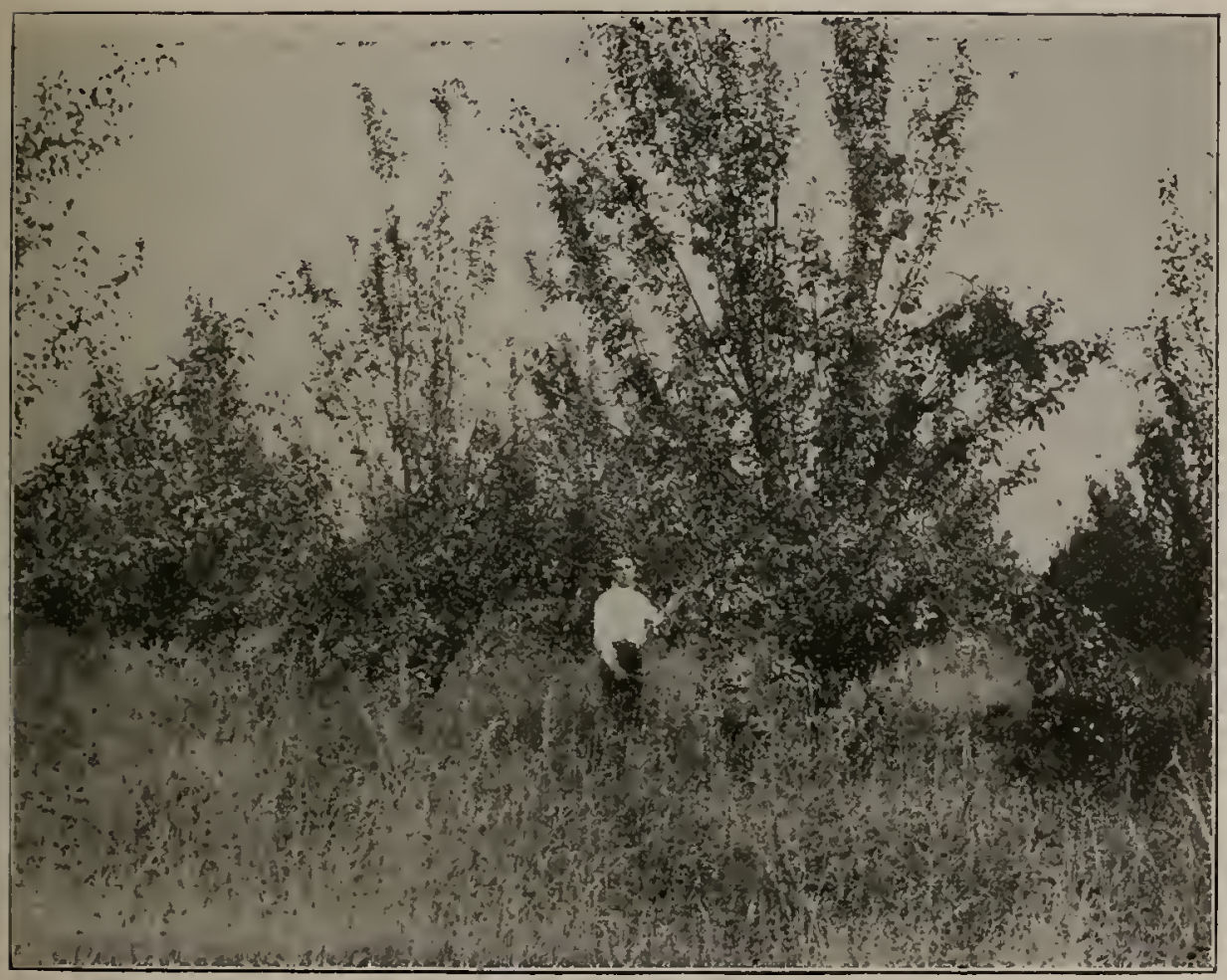

Pear orchard, Flora, Clay Co., quail's nest found near tree in foreground. 
Plate IV.

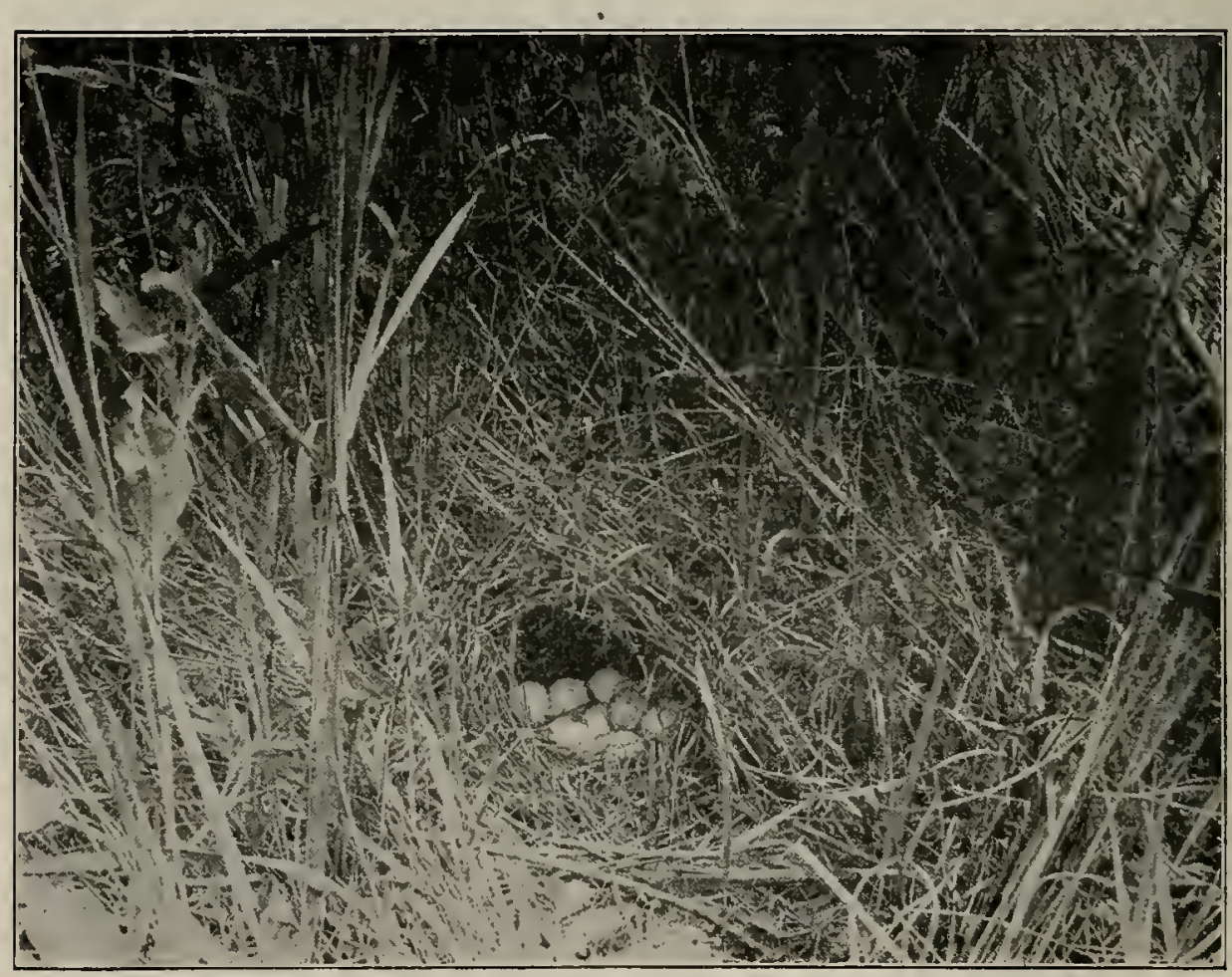

Quail's nest, with 16 eggs, from orchard near Benton, Franklin Co., June 22, 1907. 


\section{Plate V.}

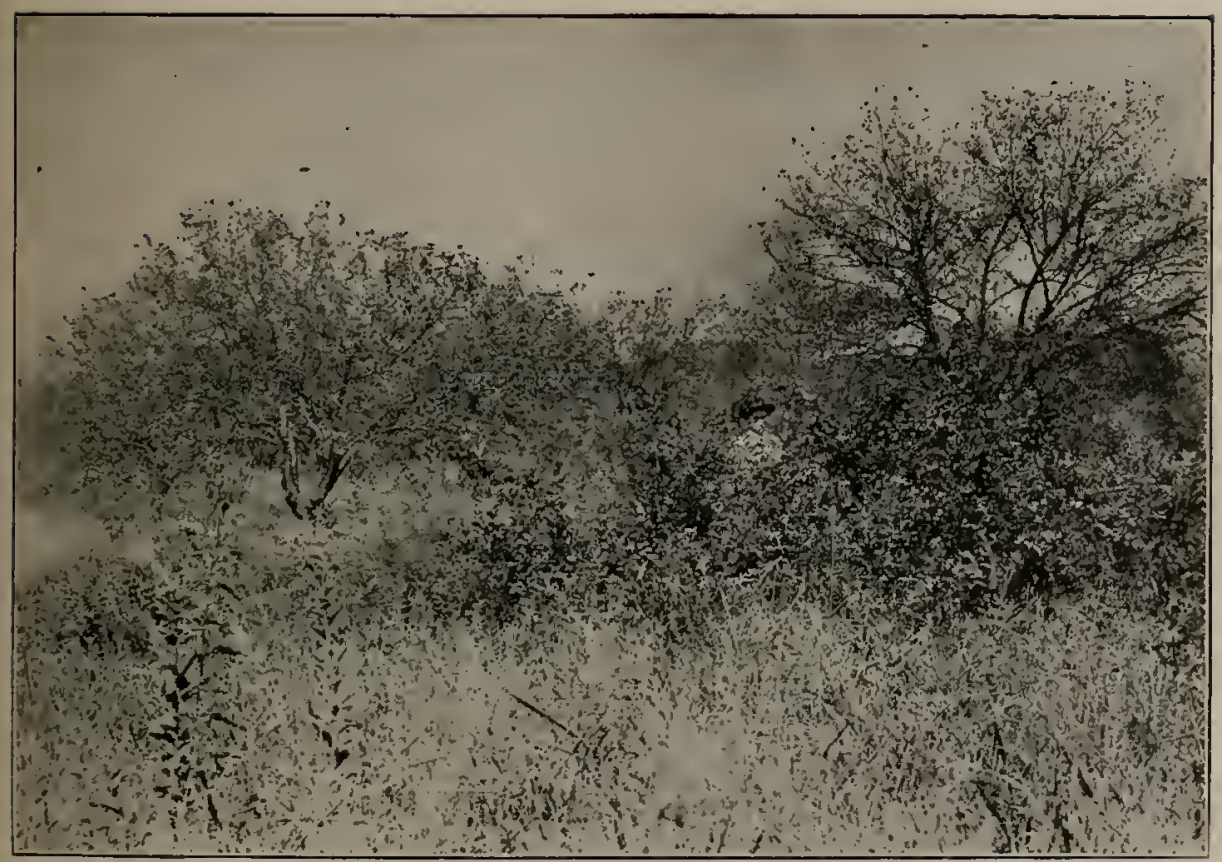

Orchard of grass, weeds, and dewberries, near Salem, Marion Co. 
Plate Vi.

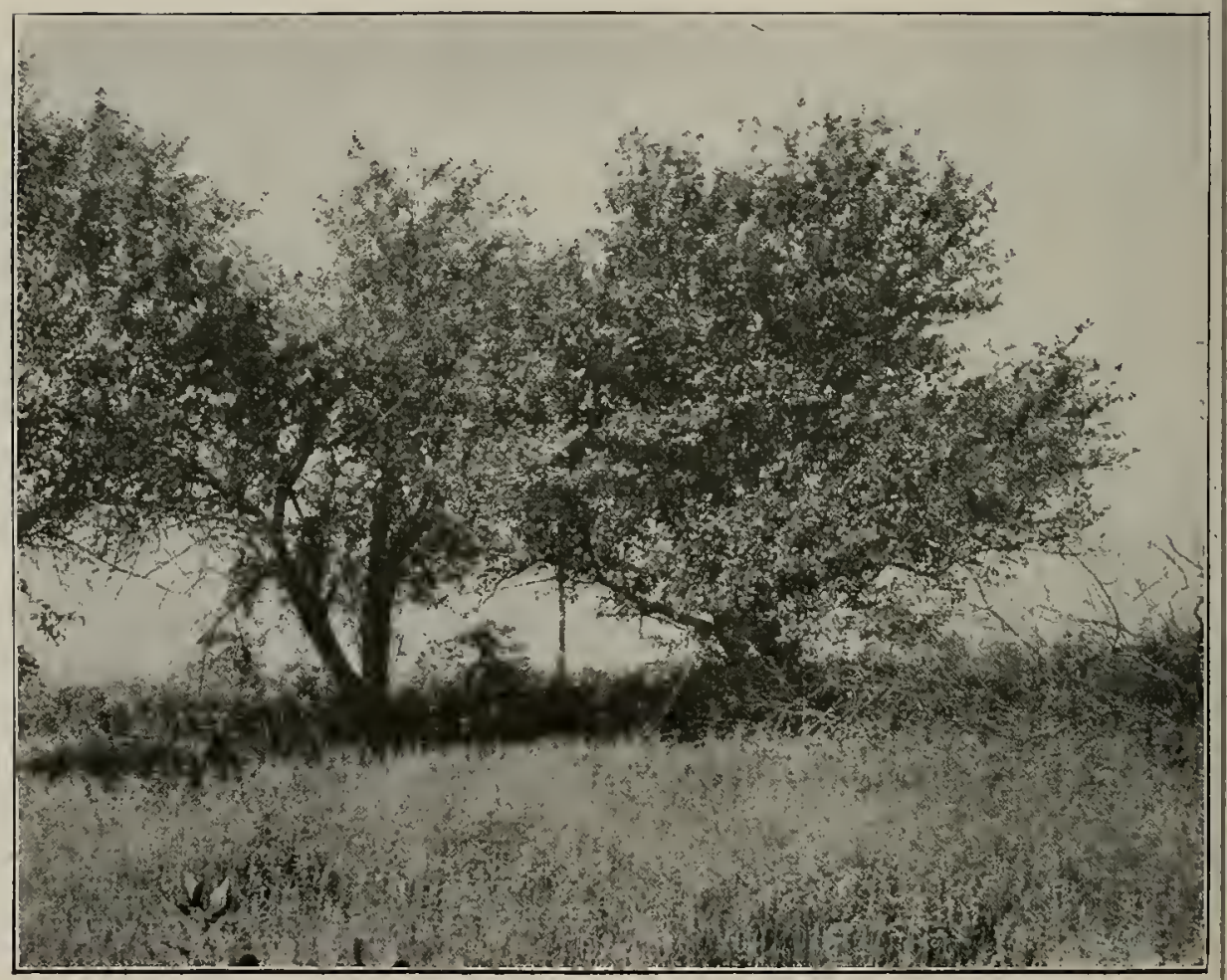

Edge of old neglected orchard near Arcola, Douglas Co., June, 1908. 